University of Wollongong

Research Online

Faculty of Social Sciences - Papers (Archive) Faculty of Arts, Social Sciences \& Humanities

2018

Unintentional path dependence: Australian guitar manufacturing, bunya pine and legacies of forestry decisions and resource stewardship

Christopher R. Gibson

University of Wollongong, cgibson@uow.edu.au

Andrew T. Warren

University of Wollongong, awarren@uow.edu.au

Follow this and additional works at: https://ro.uow.edu.au/sspapers

Part of the Education Commons, and the Social and Behavioral Sciences Commons

Research Online is the open access institutional repository for the University of Wollongong. For further information contact the UOW Library: research-pubs@uow.edu.au 


\title{
Unintentional path dependence: Australian guitar manufacturing, bunya pine and legacies of forestry decisions and resource stewardship
}

\author{
Abstract \\ Australian guitar manufacturers are increasingly competitive globally, known for quality, design, and \\ sustainability. Also distinguishing Australian guitar making is the use of native timbers $i$ a result of \\ unforeseen historical endowments of available trees from earlier eras of colonial appropriation and State- \\ sponsored planting. We develop a critical-materialist, and historical, evolutionary economic geography to \\ trace an example of unintentional path dependence. Present craft-based manufacturing is linked to past \\ regimes of resource stewardship. We illustrate this through the example of the bunya pine (Araucaria \\ bidwillii), an endemic tree with Indigenous significance now used industrially as a ¿tonewood $i$ in guitar \\ making. With limited geographic range, bunya was planted by State forestry during the inter-war period, \\ considered $i$ useful $i$ in difficult locations where other industrial species failed. Reflecting prevailing \\ stewardship norms, bunya trees were pruned and cared for, even though always considered marginal. \\ Abandoned as an industrial forestry species, a half century later surviving cultivated bunya trees were \\ rediscovered for guitar making. From this case, we argue that economic geographers remain attentive to \\ material resource histories, as antecedent to contemporary configurations. Earlier decisions, ideologies \\ and labour processes bestow present generations with available material resources, enabling new \\ geographic concentrations of expertise. Acknowledging how historical materialities of resource \\ stewardship reverberate unpredictably in the present, guitar makers and tonewood specialists are \\ contemplating prospects for longer-term scarcities, and experimenting in anticipation of them now.

\section{Disciplines} \\ Education | Social and Behavioral Sciences

\section{Publication Details} \\ Gibson, C. \& Warren, A. (2018). Unintentional path dependence: Australian guitar manufacturing, bunya \\ pine and legacies of forestry decisions and resource stewardship. Australian Geographer, 49 (1), 61-80.
}


Gibson, C and Warren, A (2018) Unintentional path dependence: Australian guitar manufacturing, bunya pine and legacies of forestry decisions and resource stewardship. Australian Geographer, 49, 1, 61-80.

https://doi.org/10.1080/00049182.2017.1336967

\begin{abstract}
:
Australian guitar manufacturers are increasingly competitive globally, known for quality, design, and sustainability. Also distinguishing Australian guitar-making is the use of native timbers - a result of unforeseen historical endowments of available trees from earlier eras of colonial appropriation and state-sponsored planting, when future industrial uses of cultivated timber were unknown. We develop a critical-materialist, historical approach to evolutionary economic geography, to trace what we describe as an unintentional path dependence that links present craft-based manufacturing to past regimes of resource stewardship. We illustrate this through the example of bunya pine (Araucaria bidwillii), an endemic tree with profound Indigenous significance now used industrially as a 'tonewood' in guitar-making. With limited geographic range, bunya was planted by state forestry during the inter-war period, considered 'useful' in difficult locations where other industrial species failed. Reflecting prevailing stewardship norms, bunya trees were pruned and cared-for, even though always considered marginal. Superseded as an industrial forestry species by hoop pine (Araucaria cunninghamii), a half century later surviving cultivated bunya trees were re-discovered for guitar-making as a substitute for increasingly scarce North American spruce. From this case, we argue that economic geographers remain attentive to material resource histories, as antecedent to contemporary configurations. Earlier decisions, ideologies and labour processes bestow present generations with available material resources, enabling new geographic concentrations of expertise. Acknowledging how historical materialities of resource stewardship reverberate unpredictably in the present, guitar-makers and tonewoods specialists are contemplating prospects for longer-term scarcities, and experimenting in anticipation of them now.
\end{abstract}

Keywords: evolutionary economic geography, temporality, lock-in, care, bunya pine, guitar making 


\section{Introduction}

The Australian guitar manufacturing industry is increasingly prominent globally, exporting instruments in growing numbers, and known for its distinctive use of native timbers. Two Melbourne-based manufacturers, Maton (est.1946) and Cole Clark (est. 2001), are the industry leaders. They together employ a hundred people, and now produce over 13,000 guitars annually. A lively scene of luthiers also extends across Australia - solo operators who follow the European tradition hand-making guitars in small numbers using time-honoured techniques and tools (Gore and Gilet 2011; cf. Dudley 2014). The roll-call of musicians who have used Australian guitars reads like a who's-who of popular music history: George Harrison, Keith Richards (who recorded the immortal riff for the Rolling Stones hit, Gimme Shelter, on a Maton EG240 Supreme), Elvis Presley (in Jailhouse Rock); and Australian icons Paul Kelly; INXS, Midnight Oil and Tommy Emmanuel (McUtchen et al 2016). Given debate about the uncertain future of domestic manufacturing, Australian guitar making appears an emblematic case worthy of economic geographic analysis.

The development of design and craft expertise over successive decades, as well as use of new technologies, has been important to market success. Maton and Cole Clark are both highly advanced manufacturing firms combining automation with craft skills among specialist workforces. But success has also stemmed from the materials from which Australian guitars are made - their timbers ('tonewoods') not widely used elsewhere. They are viewed as much more ‘sustainable’ compared with iconic American brands, the latter continuing to rely on increasingly scarce, and more tightly regulated tropical timbers such as rosewoods (Dalbergia spp.) and ebonies (Diospyros spp.) imported from Africa and southeast Asia. Maton pioneered use of Australian timbers in guitar manufacturing as far back as the 1950s. Its current range, and that of Cole Clark, is dominated by native timbers. Standard lines as well as higher-end models from both companies make use of blackwood (Acacia melanoxylon), Queensland maple (Flindersia brayleyana), and bunya pine (Araucaria bidwillii). Guitar making is a distinctive, high-value manufacturing niche, linked to histories of sawmilling and forestry via longer-run inheritances in available material resources. 
Musical instrument firms in Melbourne's anonymous eastern suburbs are intimately connected with plantations, sawmills, and rainforests across regional Victoria, Tasmania, and Queensland. Inspired by Ian Cook’s (2004) method of geographically 'following' commodities and their imbued social relations and environmental impacts, this article follows Australian acoustic guitars all the way back to the tree, and to one particular species - bunya pine - with a distinctive historical geography.

Of profound Indigenous significance, bunya pine was identified and appropriated by colonial actors, and then in the early twentieth century planted by state forestry in locations where other species wouldn't grow. This was an era defined by a productivist ideology, in which an emergent state-sponsored forestry regime sought to find 'useful' solutions to natural resource management problems (Dargavel 1995). Although successfully grown in marginal geographic locations, bunya was overshadowed commercially by more 'productive' species and thus never favoured by industrial-scale foresters and downstream wood-products sectors. Yet cultivated, pruned and cared-for during the productivist regime of the mid $20^{\text {th }}$ century, as was the norm for all forestry species, those bunya trees eventually grew into high quality trees suitable for guitar-making. They have since become part of a new supply chain linking musical instrument manufacturers with a distinctive Australian tonewood, at a time when sustainability, 'Australianness' and 'nativeness' have proved marketable (cf. Trigger et al. 2008; Pike 2015). Still marginal to larger industrial-scale forestry, bunya's continued survival in forestry coops is unclear, within a new regime of privatised forestry in which returns to shareholders reigns supreme. Uncertain that a state forestry regime will sustain guitar-making indefinitely, manufacturers and tonewoods experts are taking matters into their own hands, experimenting with plantings on private land for future use beyond their own lifetime. Tracing the contingent temporalities of this story, we seek to show how historical resource stewardship decisions, practices and ideologies reverberate precariously in the present.

In so doing we make the case for an historically-enriched economic geography that links present craft and manufacturing expertise to past natural resource management 
regimes - that focuses not just on contemporary dynamics that shape present distributions of activity and expertise, but also the contingent temporal processes, past actors and decisions, and lingering materials, shaping how things come to be. We thus engage with the growing field of evolutionary economic geography, and its accompanying concepts of path dependence and 'lock-in', alongside literatures on the historical geography of craft skill, to provide a temporal framework within which to interpret how past approaches to resource exploitation bestow present economic actors with unforeseen opportunities. We advocate for a critically-grounded, and historical approach - sensitive to questions of resource materiality, the ideologies and power relations that come to bear on those resources, and pressing issues of scarcity set against the prospects of ever-increasing rates of human consumption. From the case of a niche manufacturing industry (guitars) and a single tree species (bunya pine), stems broader insights on how unintentional path dependence creates historical-material resource legacies that resonate throughout time.

\section{Historical resource stewardship and materiality: enriching economic geography}

Historicity and temporality are growing concerns in economic geography, exemplified in the growing popularity of evolutionary theories. Flirting with Darwinian metaphors, evolutionary approaches theorise present distributions of economic activity, and accompanying dynamics of stasis and change, as outcomes of evolving past relations, processes, policies, and events (Stewart 2016). A pathdependent process or system is 'one whose outcome evolves as a consequence of the process’s or system’s own history’ (Martin \& Sunley 2006, p.399). Product design, technologies, institutions and organisations are ‘locked-in' by decisions, and settle into place via ideologies and norms; they "reverberate through history, closing alternative paths and validating a particular path” (Martin \& Sunley 2006, p.401). Evolutionary approaches invite overdue acknowledgement of history and contingency to economic geographical analyses.

Nevertheless, evolutionary economic geography has been subject to widespread criticism, especially in political economy, where it is considered overly uncritical, abstract, and immaterial (e.g. McKinnon et al 2009; Hudson 2012; Gibson 2016). 
Among the unresolved critiques catalogued by Martin and Sunley (2006) are the degree to which there are different types of path dependence, under varying circumstances; the intentionality (or otherwise) of path creation and destruction; and whether lock-in effects are necessarily inefficient or negative.

Responding to Martin and Sunley (2006), the case presented here is a prime example of what could be described as unintentional path dependence: historical processes that lock in present concentrations of activity or expertise, arising from unplanned or unforeseen sequences of events, decisions, or actions. A critical-materialist and historical geographic analysis of resource use explains how the current 'market shape of things' (Polanyi 1977: xl) has come to be. Material resources are configured and reconfigured within systems of exchange, distribution, production, and consumption (Bridge 2009), subject to successive 'resource regimes' (Dargavel 1995, p. 2) that lock together in time and place certain approaches to natural resource management, legal-technical systems (land tenure, exclusive rights, concessions), processors and downstream distributors, retailers and end-users.

In the example below, a sequence of decisions, ideologies, practices of cultivation and care, and relationships between actors, locked in the market shape of commerciallyavailable bunya pine. It is not so much that markets 'naturally' emerged for native timbers as inputs for contemporary craft production, but that material presences and the availability of certain timbers for manufacturers is dependent on a sequence of successive regimes that locked into place species, actors and relationships, within Indigenous, colonial, state-industrial and privatised phases of forestry. That sequence unfurled in ways that enable the contemporary use of relic stands of bunya for a niche craft-based industry, but that also render its future uncertain. The same forces that saw bunya pine sidestepped as an industrial timber in the post-World War II period (thus enabling it to survive, unfelled, to grow big enough to become useful for guitar manufacture) also threaten it as a contemporary niche species.

In light of this critical-materialist and historical approach to evolutionary economic processes, we also draw inspiration from recent efforts to more deeply ground 
analysis of craft practice and manufacturing in historical contexts (Patchett 2017; Luckman \& Thomas 2017). As Jakob and Thomas (2015, p. 1) argue, 'legacies of past practice often inform contemporary agendas'. The twist here is to connect this emerging appreciation of historical geographies of craft and manufacturing not only with antecedent maker traditions, skills and knowledge (cf. Patchett 2017), but to the vital input material resources themselves - and their own genealogies and cultural meanings, past practices of care pertaining to them, and accompanying forms of expertise. In this case, current craft practice and path dependent development of expertise around high-value cultural production (for commodities such as guitars) must be understood as linked to unintentional path dependence on past resource cultivation and stewardship, within a context of foreboding material-ecological relations (Carr \& Gibson 2016). The story of Australian guitars, then, is also one of forests, forest managers and custodians, past and present, and the very trees from which they are made.

\section{Methods}

This paper stems from a wider project making connections between contemporary craft, manufacturing and cultural industries and upstream forestry resource sectors (see Gibson \& Warren 2016). As part of that project we visited a dozen guitar factories (including both Maton and Cole Clark) and luthiers, where labour process, materials and techniques were observed, and especially where resource procurement experts were interviewed. Snowballing from these interviews, we also visited upstream tonewoods supply specialists, sawmills, and foresters in Tasmania, Queensland, Hawai'i and the Pacific Northwest, United States. Although the wider project has encompassed fieldwork internationally, this paper focuses only on the story of Australian guitar manufacturers, tonewoods specialists, and upstream timber suppliers. And although numerous Australian timbers are now part of the guitarmaking scene, we focus especially on the case of bunya pine. This enables close retrieval of the sequence of events, decisions, and actions that constitute a distinctive unintentional path dependence around one tree species. From our much larger set of interviews, we thus only draw upon transcripts of interviews with those relevant to the story of bunya: Patrick Evans, Manager of R\&D, Projects and Product Development at Maton; Miles Jackson, CEO at Cole Clark; and especially David Kirby, Australia’s 
key bunya tonewood supplier (interviewed three times in person at his sawmill facility, and twice over telephone). These interviews, conducted between 2015 and 2017 (and quoted from directly below), were recorded and then transcribed.

Technical knowledge of forestry and guitar construction also underpinned our methodology. John Huth at the Queensland Department of Agriculture and Fisheries (a forestry scientist and preeminent historian of bunya pine) provided technical feedback on bunya pine, while insights on guitar engineering and timber were provided by Miles Jackson, David Kirby and Patrick Evans. Bunya is now is widely used for soundboards (also known as guitar tops or faces) in guitar-making. Soundboards are viewed among guitar makers and players as the 'heart and soul of the instrument' (Morrow 2007, p. 27): they project and reverberate the amplified sounds of plucked strings via the guitar's bridge (where the strings join the main guitar body). For this reason, soundboards are the single most critical component of guitar design to influence overall tonal qualities. Soundboards need to be strong enough to withstand enormous string tension, while light in weight, and able to reverberate freely in ways that do not impede sound wave projection - all the while being aesthetically pleasing. Tonewoods used for soundboards must have high alonggrain stiffness (elasticity) relative to a low density (or mass) (Morrow 2007). Internationally, sitka spruce (Picea sitchensis) is most commonly used. It comes from old growth forests in Alaska and British Columbia, from trees 200-400 years old. Reliance on dwindling numbers of very old trees from virgin forests means looming shortages and higher prices for high-grade spruce soundboards: 'although only around 150 logs are dedicated to soundboard production each year, the overall harvesting rate is anticipated to result in a shortage of large diameter logs... within 15-30 years' (Morrow 2007, p. 16). Bunya pine is a rare example of an alternative species with requisite qualities of lightness, straight grain, stiffness and strength, that has also been accepted by guitar players as looking and sounding good. How this came to be was an important, species-specific thread within our overall project, and thus became the story at the centre of this paper.

Supporting primary fieldwork was the use of a range of secondary historical 
materials, sourced from academic publications, forestry industry reports and conference proceedings, Queensland archives, and photographic records. Consulting such materials enabled us to verify events in the history of bunya pine, as recounted to us by contemporary guitar manufacturers and tonewoods suppliers. They also provided sufficient detail on Indigenous and colonial histories of bunya pine, to reconstruct an historical economic geography of the tree as a forestry species. That narrative forms the first part of our empirical story below. It is followed by another narrative, that in due course intersects with the first, on use of native timbers in Australian guitar manufacturing.

\section{Historical geographies of bunya pine}

Bunya pine has since time immemorial been of deep significance for Aboriginal people. In Gubbi-Gubbi country it is called bonyi (Queensland Museum 2016), while colonial-era explorers recorded it being variously described as 'banza-tunza', 'bahnua' and 'boonya' (Huth 2002, p. 4). A 'towering, majestic tree' with 'a certain nobility of habit' (Huth \& Holzworth 2005, p. 5), it grows in excess of 45m high, with a trunk diameter of up to $1.5 \mathrm{~m}$. Its dome-shaped crown is visible from great distances; it grows perfectly straight, with whorling horizontal branches, in the words of then Queensland Forest Service Director, E.H.F. Swain (1928, p.66), 'ropy limbs, radiating horizontally in bewildering multiplicity’ (Figure 1). On females grow iconic giant cones $(30 \mathrm{~cm})$ that weigh up to $10 \mathrm{~kg}$ each. Indigenous groups from southeast Queensland and northern New South Wales consider the bunya sacred; their edible seeds a ceremonial food of profound importance.

$<$ Figure 1 about here $>$

Presiding over the bunya were custodial rights and obligations, 'built up through generations of interaction with the bunya forests' (Haebich 2003, p.47). Early colonial reports were that 'every tree was said to belong to some particular family' (North 1893, p. 160). Major seasonal ceremonial gatherings brought together thousands from a wide area - typically when the bunya pines experienced 'bumper' crops (around every three years) (Huth \& Holzworth 2005, p. 6). Ceremonies were performed, songs 
and dances shared, disputes adjudicated, marriages arranged, and goods traded. Bunya pine was an important economic resource; the nuts provided carbohydrate and could be stored for years, eaten raw, roasted or ground into flour ((Mabberley 2001: 32), while 'the headman of the Kaiabara tribe wore an armband made of bunya fibre as a mark of office and the bark of dead trees was used as fuel' (Huth \& Holzworth 2005, p. 6). When in abundance nuts were traded in exchange for moratoria on animal hunting; in the words of one colonial botanist, a 'queer form of game-preserving' (North 1893, p. 160). The gum and roots were also a food source.

Escaped convicts from the Moreton Bay settlement in the early 1820s were said to be the first Europeans to witness bunya pine (Haebich 2003). Early colonial explorations identified natural stands of bunya and other Araucaria species in southeast Queensland that were ideal for use in horticulture and forestry. In 1823, explorer John Oxley sailed the Brisbane River and found abundant stands; returning the year after with botanist Allan Cunningham, he described hoop pine (Araucaria cunninghamii) as the 'monarchs of the woods'. Bunya pine (Araucaria bidwillii), meanwhile, was named in honour of John Bidwill (1815-1853), an explorer, botanist, and the first Land Commissioner for Crown Lands. Endemic to Queensland, it was found to be 'extraordinarily limited in range' (Swain 1928, p.67) in the Bunya Mountains and Blackall ranges in the south-east, and two smaller, adjacent areas in the north of the state (Huth \& Holzworth 2005).

Early colonists were captivated by the bunya's size, striking silhouette, giant cones, and obvious Indigenous significance. It 'held a fascination for colonial artists, natural scientists, entrepreneurs and gardeners' (Haebich 2003, p.47), a 'dark, gloomy, threatening tree, overwhelming in size, and sublime in its capacity to elicit awe' (Buckridge 2012, p. 173). Bunya gathering feasts were 'mythologised in colonial writings as mystical, primeval ceremonies and barbaric rituals' (Haebich 2003, p. 47; see also McKay \& Buckridge 2002). Conversely, colonial scientists and horticulturalists viewed bunya as 'a useful and civilised tree' (Buckridge 2012, p. 173); they spread the range of the plant, sending nuts through personal networks for private and commercial use, taking 'little notice of the fact that this conflicted with 
Indigenous prohibitions on planting the bunya in other locations' (Haebich 2003, p. 49). Strict Indigenous taboos prevailed over the bunya, preventing it being cut down. Conflict with colonists keen to cut bunya for its straight-grained timber inevitably ensued.

As a consequence, the bunya pine was one of the few trees (indeed perhaps the only tree) to have been protected for sole use by Aboriginal people, in the 1842 Bunya Proclamation by the Governor of the New South Wales colony (Huth \& Holzworth 2005, p. 6). Further 'illegal’ logging nevertheless followed, and in 1859 the Bunya Proclamation was rescinded by the newly formed State of Queensland. This led to widespread timber-cutting without Indigenous consent, further violent conflict, and renewed concerns about the survival of native pine species. Events culminated in the creation in 1908 of Queensland's second national park, the Bunya Mountains National Park. Less than one percent of total land area of the Bunya Mountains National Park is now covered by the bunya pine species.

Over time Europeans 'assumed custodianship of the bunya pine, assimilating it into Western scientific, economic, legal, horticultural, environmental and symbolic systems, which replaced Indigenous custodial rights, obligations and knowledge' (Haebich 2003, p. 47). Specimens were sent to and grown in the Temperate House at Kew Gardens in London and as an ornamental tree it was planted in botanical gardens as distant as Naples, Trinidad, Singapore, and Auckland (Haebich 2003). Its distribution reflected British imperial networks of explorers, scientists, botanical gardens, and nurseries. ${ }^{1}$ Bunya pines were by the turn of the twentieth century widely available in nursery catalogues, sourced cheaply from government forestry plantations. It was increasingly grown as street trees, windbreaks, and in school playgrounds. A 'public, institutional tree’ (Buckridge 2012, p. 176), its ‘symmetrical shape, domed crown, straight trunk, height, and exoticism fitted well with fashions in nineteenth century gardening and landscaping' (Haebich 2003, p. 50). Bunya became a signature civic tree species, featuring in Victorian-era cemeteries, around homesteads and churches, lining memorial avenues, and around city statues and war epitaphs. 
From this phase of colonial appropriation and experimentation emerged nascent forestry uses. Unique genetic traits that gave rise to the bunya pine tree's distinctive appearance - especially its upright growth habit - made it useful for cabinet-making and other purposes. Logs were huge in diameter (Figure 2). Its timber was pale yellow with an even texture, and faint parallel straight grain. From its rise to prominence in the late 1890s up until the 1930s, along with hoop and kauri pine (Agathis robusta), it was commonly used for flooring, casks, boat masts and booms, broom handles, butter boxes, and to line and seal wooden homes (Huth 2002). During this time, the group of endemic Araucaria pines were conflated together, simply known collectively as 'Queensland pine'. All were heavily cut and used throughout the 1800s (Figure 3), leading to grave concerns about their survival. In 1901, a Forestry Branch of the Department of Public Lands was formed to enact governmental control over previously unregulated timber harvesting (Huth \& Holzworth 2005). By 1917 the need for plantations of Araucaria to supplement depleted endemic stands was clearly apparent, and under E.H.F. Swain's direction of the Queensland Forest Service plans were made by the to phase out harvesting from remaining old growth forests under state control, while massively expanding forestry trials and plantings.

$<$ Figure 2 about here $>$

$<$ Figure 3 about here $>$

An early phase of converting native species to plantations followed (Taylor 1994), as forestry entered a new 'resource regime’ (Dargavel 1995, p. 2) characterised by statesponsored experimentation, mechanisation, industrial-scale volumes, and centralised and more capital-intensive sawmilling. Productivist ideologies infused new forestry thinking - a rational approach to forest cultivation (rather than 'hillbilly' plundering of old growth) and the industrial usefulness of native species paramount. Swain, everdiligent, listed in his 1928 industrial forestry manifesto no less than 850 potential uses of native timbers across all manner of products, from aircraft to artificial limbs, scythe handles to railway sleepers. Early growth trials were encouraging. The first commercial plantations were established in the 1920s at Imbil and Yarraman (near 
Gympie) on cleared sites that previously held Araucaria within native forests (Dieters et al 2007). It was an era of significant research, trial and error, and technological advances in nursery systems and tree breeding (Taylor 1994). Over successive decades many further thousands of hectares were planted; forestry scientists searched for superior specimens, planting over 200,000 hoop pines in progeny tests, and establishing specialist clonal seed orchards (Dieters et al 2007). Three other Araucaria species planted were klinki pine (A. hunsteinii), Norfolk Island pine (A. heterophylla), and Paraná pine (A. angustifolia) (Huth \& Holzworth 2005, p. 9). Beyond conifers, Queensland maple (Flindersia brayleyana), originally from northern Queensland, was also planted in the region. Unrelated to northern hemisphere Acer varieties of maple (and more closely related to citrus trees), Queensland maple too would later become a staple of guitar-making in Australia (though being a hardwood, it was more suited to backs, sides and necks rather than soundboards). In 1924 a systematic approach to nursery production was established in order to cultivate seedlings. By the 1930s the total area under plantation had reached 1250 hectares.

Bunya occupied a distinctive niche within this emergent state-sponsored forestry regime, a consequence of its unique characteristics, and technological changes from the earlier era of colonial extraction. Although hoop pine was rapidly emerging as the dominant species in newly planted coops, it was susceptible to frost, a problem in low-lying gullies and paddocks. In an earlier era, horses used by timber-getters grazed in such spaces. Industrial forestry then brought with it the advent of trucks, rendering old horses (and their paddocks) redundant. Fitting with the productivist ideology of the era, state foresters sought to make such sites more 'useful'. Bunya, frost resistant but also straight-growing, fitted the bill, and was planted (along with silky oak, Grevillea robusta) in these difficult spots (Huth, pers. com. 2017).

In due course the practices of thinning and of removing lower limbs of planted pines began. Handsaws were used to prune off lower limbs to ensure knot-free timber 'for an expected future plywood market' (Huth \& Holzworth 2005, p. 3). In a sequence of stages over several years, pines were pruned to a height of 21-feet (6.5 metres) using 9, then 12 and 16-foot ladders. Although always considered marginal, bunya pines 
were cared-for in the same manner as other planted Araucaria, although not without difficulties. John Huth, who himself participated in prunings as a younger forester, recalled it as difficult work; there were inherent dangers working at height, and bunya pine was 'prickly stuff', with unhelpfully thick bark. On trunks already pruned, new whorls of epicormic shoots would emerge, requiring further subsequent pruning. Even though foresters doubted whether such pruning practices were worthwhile, they were nevertheless undertaken. Cultivating trees in this way, with care, was simply what foresters did, in order to maximise possibilities of future usefulness of knot-free timber. Such practices of stewardship and care would, it turns out, prove vital for $21^{\text {st }}$ century guitar-makers, who required knot-free, quarter-sawn timber $^{2}$ of sufficient width, with dead straight parallel grains for use in guitar soundboards. Tonewood specialist David Kirby (who we will hear from in more detail below), remains evergrateful for foresters' earlier stewardship mentality and practices of care: 'they were public servants, and they had an MO [modus operandi]. What's good for production, because they're foresters, but for the public good rather than trying to maximise the profit; they were thinking more of a long-term thing'. Had those earlier stewardship practices of pruning with care not occurred, the cultivated bunya would have proved too knotty for later use.

Of all the Araucaria, ultimately only hoop pine succeeded as a widespread monocultural industrial forestry species. Kauri pine was subject to successive pest attacks, and was abandoned. Bunya grew too slowly to ensure maximum yield in the minimum possible time. In the hard language of forestry science,

plantation establishment is governed by a basic economic rationale, where rotation times (plantation establishment to harvest date), internal rates of return, and commodity production prices dictate site establishment and species selection. The comparatively slow growth rate of bunya pine and the general overlap in target products with faster grown species has contributed to the abandonment of its planting. (Morrow 2007, p. 18)

In addition, the large sawmills associated with the industrial forestry regime had been equipped for smaller-diameter hoop pine. Processing a single species brought economies of scale, less need for skilled and adaptable labour, and obviating having 
to re-tool and run varying thicknesses. Bunya’s sticky knots and thick bark threatened expensive blades. It proved more difficult to treat than other pines, while its waste product, frequently burnt by mills as fuel, generated a messy and unwelcome resin. Mulching techniques also emerged that prevented frost burn of hoop pine in gullies. Planting further bunya pine became unnecessary.

By the 1970s, hoop pine had clearly emerged as the most profitable of all the native Araucaria subject to earlier forestry plantings; it was accepted in a variety of downstream industrial uses and, in the terminology of evolutionary economic geography, sawmilling technologies and labour process had accordingly locked into place around it. By the 2000s the hoop pine estate in southeast Queensland had spread over more than 44,000 hectares, about a quarter of the state's total plantation forests (Huth \& Holzworth 2005). Bunya, by comparison had at its peak at 510 hectares. Effectively abandoned by industrial forestry, by 2005 there were only 368 hectares of bunya plantation left.

\section{Australian guitar manufacturing and native timber use}

Guitar manufacturing has its own historical geography. In due course this intersected with the above lineage of native timber forestry. Guitars emerged in Australia as a domestic manufacturing concern in the period following World War II. Cabinetmaker and woodwork teacher Billy May (who moonlighted as a bass player in local jazz and Hawaiian acts) started making guitars in 1946 in his suburban Melbourne garage. Imported American instruments were not only delicate to transport but subject to high import duties, making them rare, and extremely expensive. Protectionism enabled market possibilities to emerge that supported a fledgling domestic industry. May began machining guitars in the garage, 'turning the front-end bearings of a Tmodel Ford into a bandsaw' (McUtchen et al 2016, p. 20), while his wife Vera managed financial affairs.

Resource availability was an immediate concern. Emerging from the War with its scarcities and rations, 'there were immense hurdles really, even when it came to buying wood’ (May, quoted in McUtchen et al 2016, p. 20). Local timber yards did 
not stock suitable imported timbers, which were scarce following World War II, and which would have been prohibitively expensive after import duties. Just obtaining suitable wood was a challenge: 'Vera would accompany Bill on his timber-buying expeditions. As she nursed Susan and Linda on her knee, Bill would strap the timber to the side of the car'. Maton began experimenting with native species 'out of necessity’ (Evans, pers. com. 2017). Queensland maple was first used on budget guitar necks as a substitute for imported mahogany; blackbean (Castanospermum australe) and silver silkwood (Flindersia acuminata) replaced ebony ansd rosewood for fingerboards. Plywood tops on budget guitars, much cheaper than imported spruce, almost certainly contained either bunya or hoop pine (Figure 4). According to Maton's Patrick Evans, 'there was a lot of cultural cringe on Australian timber in those days... I think had Bill been able to, I think he probably would have preferred to have been using traditional [American] woods'. Billy May recalled: 'I loved Australian timber, but in the early days, I was forced to give the local timber, like Queensland maple, a more exotic name. When I first started making guitars, many people thought 'Australian-made' meant something inferior. It took a long time to get over this attitude' (quoted in McUtchen, et al 2016, p. 13). Evans elaborated: 'we used to call it things like red mahogany or in the case of Queensland walnut, forget to mention the Queensland bit’. Only later would native timbers come to be re-valued and 're-natured' (Trigger et al 2008, p. 1273), signifying quality and sustainability.

$<$ Figure 4 about here $>$

Events further afield fuelled later experimentation with native timbers. In the United States, growing post-war affluence and the popularity of both rock 'n' roll and folk music led to exponential increases in demand for guitars. Gibson, Martin, and Fender expanded volumes accordingly. Although Maton were able to secure supplies of imported traditional tonewoods after the post-World War II scarcities had subsided, counteracting forces of massive demand in American guitar manufacture, and growing environmental regulation, made on-going, economically-viable procurement more difficult. The ratification of the Convention on the International Trade in Endangered Species (CITES) in the 1970s led to increased species protection: first 
Brazilian rosewood (Dalbergia nigra, which was effectively banned from international trade in 1992), and then ebony, and mahogany (Gibson \& Warren 2016). This affected which timbers could be easily obtained and used economically. Necessity and then new rounds of scarcity drove Australian guitar manufacturers to consider local alternatives.

Patrick Evans, who had recently started at Maton in the early 1990s, recalled: around about '94 we started looking at more native timbers... there was an economic imperative in that particularly mahogany was starting to go through the roof, price-wise. Probably the first thing we had to do was to find an alternative for mahogany and Queensland maple was the logical choice, firstly because we'd used it extensively before.

Re-valuing nativeness and emphasising the timber’s Australianness was a second key strategy in 'trying to find that point of difference, as a brand' (cf. Trigger et al 2008). On their high-end ‘Australian’ series, Maton phased in blackwood (Acacia melanoxylon; from Tasmania and Victoria) as a substitute for rosewood backs and sides, and then introduced Queensland maple. No longer a cheap substitute, anonymised on budget guitars, native timber instead became a marketable asset for high-value instruments.

This in turn led manufacturers to develop new relationships with emergent specialist tonewoods suppliers: solo operators who specialised in instrument-grade timber, who used portable sawmills or the services of small family sawmills to cut small numbers of ideal specimens on private land, or from remnant plantations on state forestry land. Evans remembered:

Around the same time, we started the ball rolling. We got in contact with a bunch of different wood people, so we started trying various things. We used jarrah on fingerboards for a while, on bridges... We then used mulga, or the various desert acacias, loads of different ones.

By the mid 1990s, once the idea of using Australian timber took off culturally within the 
company, we kept exploring, and probably the big one was looking for an alternative to spruce for the soundboard. We actually did that very methodically, in that we used Bootle [industry standard textbook on Australian wood varieties] and had the properties of spruce written down on a piece of paper, and just kept flipping through species of something that came close. Bunya came in very close, so we got some and tried it out, and it worked.

The next challenge was to secure on-going supply. Major sawmills, tooled-up and locked-in for cutting hoop pine, were uninterested in supplying it. Networks of small quality hardwoods suppliers, often operating at the edges of informality, instead filled the niche. The key supplier with access to Queensland's remnant bunyas was David Kirby. Interviewed for this research, David recalled his experience as a small-scale timber salvager, prior to specialising in guitar timbers:

I started out as a landscaper. Then I went and saw a guy who was making portable saw mills. He lived nearby and we got on really well. He said, "I need some landscaping so we'll do a swap.” I ended up with this little tiny band saw, a portable band saw. I started doing a bit of work around the place with it. Forestry started passing some work on to me. Then I started doing that as my job. For contract for other people, at first. Traveling around with portable gear...

From inauspicious beginnings, an interest in native species for guitar-making emerged, in the late 1990s:

we started supplying a lot of stuff to furniture makers. Just salvaged timber. I got a phone call one night. The guy from Maton called me up. He'd been in the area, doing some research and he wanted to try bunya for soundboards. He was trying to get someone to cut his soundboards. This call came; we were having dinner. They were heading home. They had failed. He said he could not find a sawmiller who could cut the bunya for him. I didn't even know what it was. Of course, he's going to the larger sawmills and there weren't any little mills; the big mills are saying "I don't want to know about that sort of stuff. It's too much trouble”. Anyway... he rang up. I said, “Yeah. That shouldn't be a problem”. That's how I started with Maton.

In this fortuitous but unforeseen way, bunya pine, a third key native species, was 
introduced to guitar-manufacturing supply chains. However, bunya was no longer a widely available plantation species. Surviving specimens in state forestry plantations were not (and are still not) advertised readily, nor were they accepted as part of the industrial forestry supply chain: 'It was always only 10 percent of the trees up there anyway. Basically, it got ignored, all those years no one touched the bunya trees'. Left aside while plots of hoop pine were intensively managed and harvested, the bunyas grew 'bigger and bigger... 60 years passed; they cut the hoop, another 60 years, and then the next one, and the bunya just kept on growing. So now we're on the third rotation of hoop up here and the bunya are now 80 plus years old'.

Uncertain of their exact location, Kirby developed relationships of trust with regional forestry managers; old fire trails were explored looking for tonewoods species in and amongst replanted coops of monocultural industrial forestry species. Neglected stands originally planted in gullies or as fire breaks had indeed survived. Locations were deduced from old forestry maps:

A lot of the stuff there is no information on. To find out where the plantings are I had got a forestry map of the whole area and I have to get a magnifying glass and go through it inch by inch by inch like this, and then colour around it where I found them, and there's still more that aren't on the map too.

Realising there was an ongoing demand, Kirby sought to formalise relationships with the relevant forestry agency: 'he and I had a meeting with the forestry about the resource after that. I ended up getting whatever I needed out of them, which was great'.

Developing a strong technical knowledge of instrument-building as well as forestry and plant botany, Kirby (and other tonewood suppliers around Australia) fell into a liminal position between guitar manufacturers on the one hand, and the industrial forestry regime on the other. When Cole Clark was established in 2001 by ex-Maton employees, they too used bunya pine, tentatively at first, and then in even greater volumes than Maton. CEO Miles Jackson explained: 'Bunya-Blackwood is our biggest selling combination. 60 percent of our tops are Bunya. A year and half ago it was at 9 percent. We've actually changed a hell of a lot. The reason is because we 
concluded that bunya’s just a right-sounding timber'.

Although the production volumes are tiny compared with industrial-scale forestry (approximately $50 \mathrm{~m}^{3}$ or 15 trees annually, according to David Kirby, compared with $100,000 \mathrm{~m}^{3}$ of softwoods processed regionally (Queensland Government 2016)), enough resource is available, at least currently, to serve the guitar manufacturing industry (Figure 5). As Kirby explained,

We've been doing the maple and bunya out of there ever since. These days it's getting better. Originally the bunya, even though they're probably seventy years old, they were a bit small. You have got a diameter issue. Guitars don’t shrink just because your trees are smaller. Everyone wants to do a two-piece guitar so I need trees minimum of fifty-five centimetres in diameter to even get them. Now we like sixties and there just wasn't any. We were down to using forty-eights and offset hearts to try to get soundboards. These days, they're bigger. They were all planted in the twenties and pruned and cared for. They're now beautiful, great, towering things [Figure 6]. They really are impressive trees. Perfect for making soundboards. They'll be even better when they're bigger.

$<$ Figure 5 about here $>$

$<$ Figure 6 about here $>$

Securing on-going availability of bunya nevertheless required lobbying on the part of the tonewood specialist, given that bunya had become surplus to industrial requirements. In the early years of the 2000s,

Forestry wanted to get rid of it; they wanted areas like this to plant hoops. They called me, and said "In the highest office they decided all this bunya was gonna be cut down and sold for whatever they could get for it”. They said, "Look, this has come from the highest office and we can't do anything”. I went home, and I wrote letters explaining bunya: how they're important to Aboriginal people, how we're using them, what we're doing with them. How they're getting good money for 
bunyas now. "You're about to fire sell the future" I said. I sent a copy to the premier, to the premier's assistant, to the head of forestry, to the minister for primary industries. I wrote on it everybody who got sent a copy. They could not ignore me, I figured, as long as all the way up the line, they had a copy. They were personal letters, and it worked. The trees are still here.

We witnessed confidential documents (that we are unable to quote directly) that confirm that, in 2007, Queensland's forestry agency agreed to supply bunya pine for guitar-making serendipitously, as a by-product of hoop pine harvest, although forestry agencies were still considering 'best use' of bunya pine plantation sites. That could mean retention for soil and water protection, or alternatively liquidation and replacement with hoop pine.

As we write, rumours are circulating that private forestry managers ${ }^{3}$ are again reconsidering clearing certain heirloom stands of bunya in order to return that land area to hoop pine production, now in the name of efficiency of production, and maximising shareholder returns. Bunya will likely never be planted again in forestry coops; they are surviving relics of earlier uses and ideologies - 'off the grid' of mainstream forestry. Whether existing stands will survive amidst pressures on foresters to deliver maximum returns within a singular and efficient hoop pine industrial regime remains unclear. Bunya pine is nevertheless now central to a distinctive Australian craft industry - guitar manufacturing - that is increasingly successful and visible globally, and that foresters a century ago could never have foreseen.

\section{Conclusions}

We have sought to demonstrate how historical materialities of resource experimentation reverberate precariously in the present, the result of unintentional path dependence. We traced one tree species whose meanings and uses shifted from a customary Indigenous economy to a horticultural curiosity and a 'useful' forestry species during the establishment industrial forestry, only to be marginalised, and then rediscovered by a niche manufacturing industry. Native timbers now distinguish 
Australian-made guitars in a highly competitive global industry, marking them as high quality, and comparatively sustainable, 're-natured' and understood as a material that 'belongs' on a locally-made commodity (cf. Trigger et al 2008; Pike 2015). But in the rush to celebrate the use of Australian native timbers in guitar-making, it is worth pausing to reflect on the unpredicted historical pathways and networks of experts through which they have become available - as well as the on-going precariousness of native timber supplies for musical instrument manufacture.

What 'began as a necessity' for guitar manufacturing (searching for alternative timbers close to home), has 'now become a trademark' (McUtchen et al 2016, p. 167). Yet use of native species in high-value niche manufacturing sectors did not just 'come to be'; rather their presence was the outcome of unintended sequences of past decisions, norms and actions - both within nascent Australian manufacturing (as in the case of Maton's pioneering guitar-building) and in upstream resource sectors such as forestry. In the case discussed here, contemporary high-value craft industries depend on resource availabilities that in turn are the result of earlier phases of colonial appropriation, industrialisation, and prevailing stewardship practices among forestry workers, even when the trees' future commercial uses were unknown.

Meanwhile, wider political-economic circumstances continue to change in ways that will unleash further unintentional path dependencies beyond our own lifetimes. Forestry agencies around Australia have been privatised, or if state-owned they are expected to act as if private, profit-making concerns (Schirmer \& Kanowski 2005). Plantation forests now exist not just as future timber reserves, but as profitable sources of carbon credit (Osborne 2015). The debt-financed, high volume model of efficient, monocultural quick return forestry has in some parts of Australia collapsed (Beresford 2015), though a viable model persists in the Araucaria forests of southeast Queensland. Environmental campaigns have meant that ecological concerns more deeply permeate contemporary management of forest estates (Lane 2003). In many parts of the country, Indigenous people are now publicly asserting custodianship of trees; the elders of bunya country for instance pursuing recognition 'through meetings with environmental and other planning authorities, native title claims and plans to 
revive the bunya festivals and to establish related economic enterprises' (Haebich 2003, p. 54). Opportunities are emerging for traditional owners in forest management (Feary 2008), but significant economic returns are as yet limited.

In guitar-making, other alternatives to bunya pine may yet emerge, though none are at present obvious. Hoop pine is widely available but it is heavier, and more the point, is already locked into economically viable markets for plywood, floorboards and specialist products such as matchsticks. These deliver quicker returns with less labour or technical hassle for large sawmills. On plantations hoop pines are are not typically allowed to grow big enough to become guitars. Klinki pine 'has wood mechanical properties and a density range likely to be of use in acoustic guitar soundboards' (Morrow 2007, p. 18); like bunya, it was trialled in earlier phases of experimentation, though remains more susceptible to wind damage, and has thus not been pursued industrially. Morrow (2007, p. 18) even suggests that the recently discovered 'dinosaur tree', Wollemi Pine (Wollemi nobilis, also a member of the Araucariacaea family), could one day be 'a candidate for future utilisation in this area'. It certainly has the rarity cache. For backs, sides, necks and fretboards other alternatives are emerging: blackbean has been reintroduced for fretboards, and Maton are experimenting with native white mahogany (Eucalyptus acmenoides), which they roast in specialist kilns to ensure stability. Giant US manufacturer Taylor now sell expensive limited-edition guitars using Tasmanian blackwood, as well as black-heart sassafras (Atherosperma moschatum). Other species being trialled include mountain ash (Eucalyptus regnans), and huon pine (Lagarostrobos franklinii), the latter reclaimed from Tasmanian valleys drowned in the 1960s and 1970s for hydroelectricity dams.

Taking matters into their own hands, and ultimately unconvinced that mainstream forestry will guarantee future resource needs, both tonewoods specialists and guitar manufacturers are developing their own initiatives around tree planting for future generations of guitar-making. David Kirby is involved in experiments planting bunya, Queensland maple and other high-value species in mixed-species plots on private land. We also witnessed similar experiments being undertaken by furniture makers in 
northern New South Wales, and by tonewood specialists genetically-selecting and replanting hard-rock maple (Acer spp.) in the Pacific Northwest, as well as the muchrevered rosewood alternative, Acacia koa, in Hawai'i. Such actors press ahead with plantation experiments on private land, not knowing whether they will prove sustainable or economically-viable, but certain it will take many generations beyond their own for the trees to mature to a size sufficient to be made into guitars. David Kirby explains:

the sense of doing things that you're going to reap the rewards in your own lifetime, it's not how I can think. Otherwise I can't get up in the morning and do what I do. I'm planting, pruning and caring for a forest of trees that I'm not going to harvest... What has my lifespan got to do with it?

Whether they succeed or not, the case of forestry legacies and future downstream craft industries illustrates the importance of historical legacies, of viewing human agricultural and silvicultural relationships with nature beyond short-term, risk-adverse exercises in profit maximisation. Given that exacerbated ecological crisis from climate change and species extinctions appears certain within this century, contemplating longer-term scarcities, and acting in anticipation of them now, seems more urgent than ever. 


\section{Notes}

${ }^{1}$ In the 1850s the intrepid Baron Ferdinand von Mueller distributed seeds from Melbourne Botanical Gardens to Kew, in London, and other Australian and New Zealand botanical gardens. Von Mueller at the same time also distributed and planted California redwoods, as another experiment in colonial horticulture and forestry. It would become another species used by Australian guitar manufacturer Cole Clark in the $21^{\text {st }}$ century. Cole Clark now use boards from California redwoods, salvaged from public parks and gardens, from specimens originally planted from von Mueller's eager distribution efforts, but now damaged or in need of felling.

${ }^{2} \mathrm{~A}$ log can be cut in several ways, depending on anticipated use. Quarter-sawing involves cutting at an angle perpendicular to the growth rings, to maximise soundwave resonance, and to minimise risk of unwanted warping and shrinkage. For guitar-making, this means relying on large logs of sufficient width, typically beyond the scope of most industrial plantation species, which are instead harvested much younger, for quicker return, with less width. ${ }^{3}$ The sole private interest in Queensland plantation forestry is HQPlantations, who manage 340,000 ha of the state's forests, on behalf of Hancock Timber, the world's largest manager of timberland investments for private equity investors, based in Boston, United States.

\section{Acknowledgements}

Nicole Michielin provided invaluable research assistance; we also thank John Steele, Shaun McKiernan and Jenny Atchison for conversations and collaborations on the broader project. For insights we thank David Kirby, Patrick Evans, Miles Jackson and John Huth and, in David and John's cases, we acknowledge technical feedback on earlier drafts of this paper. All remaining errors are our own. 


\section{References}

Beresford, Q. (2015) The Rise and Fall of Gunns Ltd. NewSouth, Sydney.

Bridge, G. (2009) Material Worlds: Natural Resources, Resource Geography and the Material Economy. Geography Compass 3:1217-44.

Buckridge, P. (2012) Encounters with trees: a life with leaves in the Brisbane suburbs. Queensland Review 19:173-177

Carr, C \& Gibson, C (2016) 'Geographies of making: rethinking materials and skills for volatile futures’, Progress in Human Geography, 40, 3, 297-315

Cook, I. (2004) Follow the thing: Papaya. Antipode 36:642-664.

Dargavel, J. (1995) Fashioning Australia’s Forests. Oxford University Press.

Dieters, M.J., Nikles, D.G. \& Keys, M.G. (2007) Achievements in forest tree improvement in Australia and New Zealand 6: Genetic improvement and conservation of Araucaria cunninghamii in Queensland. Australian Forestry, 70:7585.

Dudley, K.M. (2014) Guitar makers: The endurance of artisanal values in North America. University of Chicago Press, Chicago.

Feary, S.A. (2008). Social Justice in the forest: Aboriginal engagement with Australia's forest industries. Transforming Cultures 3:265-290.

Gibson, C. (2016) Material inheritances: how place, materiality and labor process underpin the path-dependent evolution of contemporary craft production. Economic Geography 92:61-86.

Gibson, C. \& Warren, A. (2016) Resource-sensitive global production networks: reconfigured geographies of timber and acoustic guitar manufacturing. Economic Geography 92:430-454.

Gore, T. \& Gilet, G. (2011) Contemporary Acoustic Guitar Design and Build. Trevor Gore (2 Vols), Terrey Hills.

Haebich, A. (2003) Assimilating nature: the bunya diaspora. Queensland Review 10:47-57. 
Hudson, R. (2012) Critical political economy and material transformation. New Political Economy 17:373-97.

Huth, J.R. (2002) The bunya pine - the romantic Araucaria of Queensland. Proceedings of the International Araucariaceae Symposium, International Dendrological Society. Auckland, New Zealand, 14-17 March 2002 edited by Rod L. Bieleski and Mile D. Wilcox. pp269-280.

Huth, J. \& Holzworth, P. (2005) Araucariaceae in Queensland. Paper presented at Australian Forest History Society. Tuesday, 9 August 2005, Queensland Museum, Brisbane.

Jakob, D., \& Thomas, N.J. (2015) Firing up craft capital: The renaissance of craft and craft policy in the United Kingdom. International Journal of Cultural Policy http://dx.doi.org/10.1080/10286632.2015.1068765

Lane, M.B. (2003) Decentralization or privatization of environmental governance? Forest conflict and bioregional assessment in Australia. Journal of Rural Studies 19:283-294.

Luckman, S. \& Thomas, N.J. (2017) Craft Economies: Cultural Economies of the Handmade. Bloomsbury, London.

Mabberley, D.J. (2001) Bidwill of the Bunya-Bunya, Curtis’s Botanical Magazine 18: 31-46.

Martin, R., \& Sunley, P. (2006) Path dependence and regional economic evolution. Journal of Economic Geography 6:395-438.

McKay, B. \& Buckridge, P. (2002) Literary imaginings of the bunya. Queensland Review, 9:65-79.

McKinnon, D, et al. (2009) Evolution in economic geography: institutions, political economy, and adaptation. Economic Geography 85:129-150.

McUtchen, A., Jenkins, J. \& Divola, B. (2016) The Music that Maton Made. Scribe, Melbourne.

Morrow, A. (2007) Evaluation of Australian Timbers for Use in Musical Instruments. Gottstein Fellowship Report, Gottstein Trust, Clayton South.

North, M. (1893) Recollections of a happy life. Republished (1980) as A Vision of 
Eden, Royal Botanic Gardens, Kew.

Osborne, T. 2015. Tradeoffs in carbon commodification: a political ecology of common forest governance. Geoforum 67:64-77.

Patchett, M. (2017) Historical geographies of apprenticeship: rethinking and retracing craft conveyance over time and place. Journal of Historical Geography, 55:30-43.

Pike, A (2015) Origination: the Geographies of Brands and Branding, Blackwell, Oxford.

Polanyi, K. 1977. The Livelihood of Man. New York: Academic Press.

Queensland Government (2016) Queensland Forest \& Timber Industry: An Overview. Queensland Government, Brisbane.

Queensland Museum (2016) Bunya Mountains Gathering. Available from:http://www.qm.qld.gov.au/Find+out+about/Aboriginal+and+Torres+Strait+Islan der+Cultures/Gatherings/Bunya+Mountains+Gathering\#.WKETVekShUQ (accessed 15 February 2017)

Schirmer, J. \& Kanowski, P. (2005) A mixed economy commonwealth of states: Australia, in Garforth, M. And Mayers, J (eds) Plantations: Privatization, Poverty and Power, Earthscan, London, 101-125.

Stewart, J. (2016) Path dependence, policy learning and Australian manufacturing since the 1970s. Australian Journal of Political Science, 51:

http://dx.doi.org/10.1080/10361146.2016.1239568

Swain, E.H.F. (1928) The Timbers and Forest Products of Queensland. Queensland Forest Service, Brisbane.

Taylor, P. (1994) Growing Up: Forestry in Queensland. Allen and Unwin. Brisbane.

Trigger, D., Mulcock, J., Gaynor, A. \& Toussaint, Y. (2008) Ecological restoration, cultural preferences and the negotiation of 'nativeness' in Australia. Geoforum 39:1273-1283. 


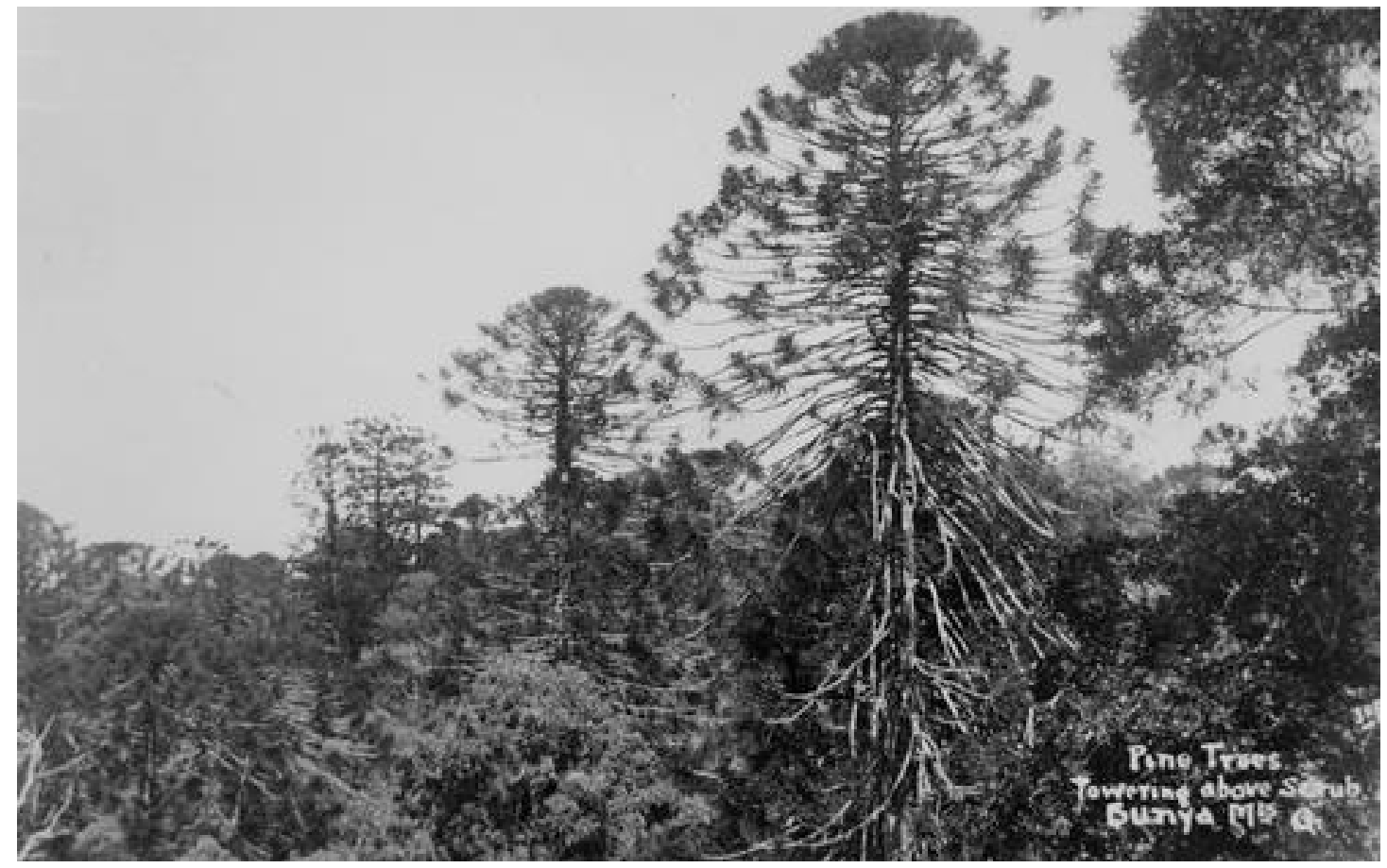

Figure 1. Foster, J. H (1920). Pine trees towering above scrubs, Bunya Mountains, ca. 1920. Reproduced with permission, John Oxley Library, State Library of Queensland 


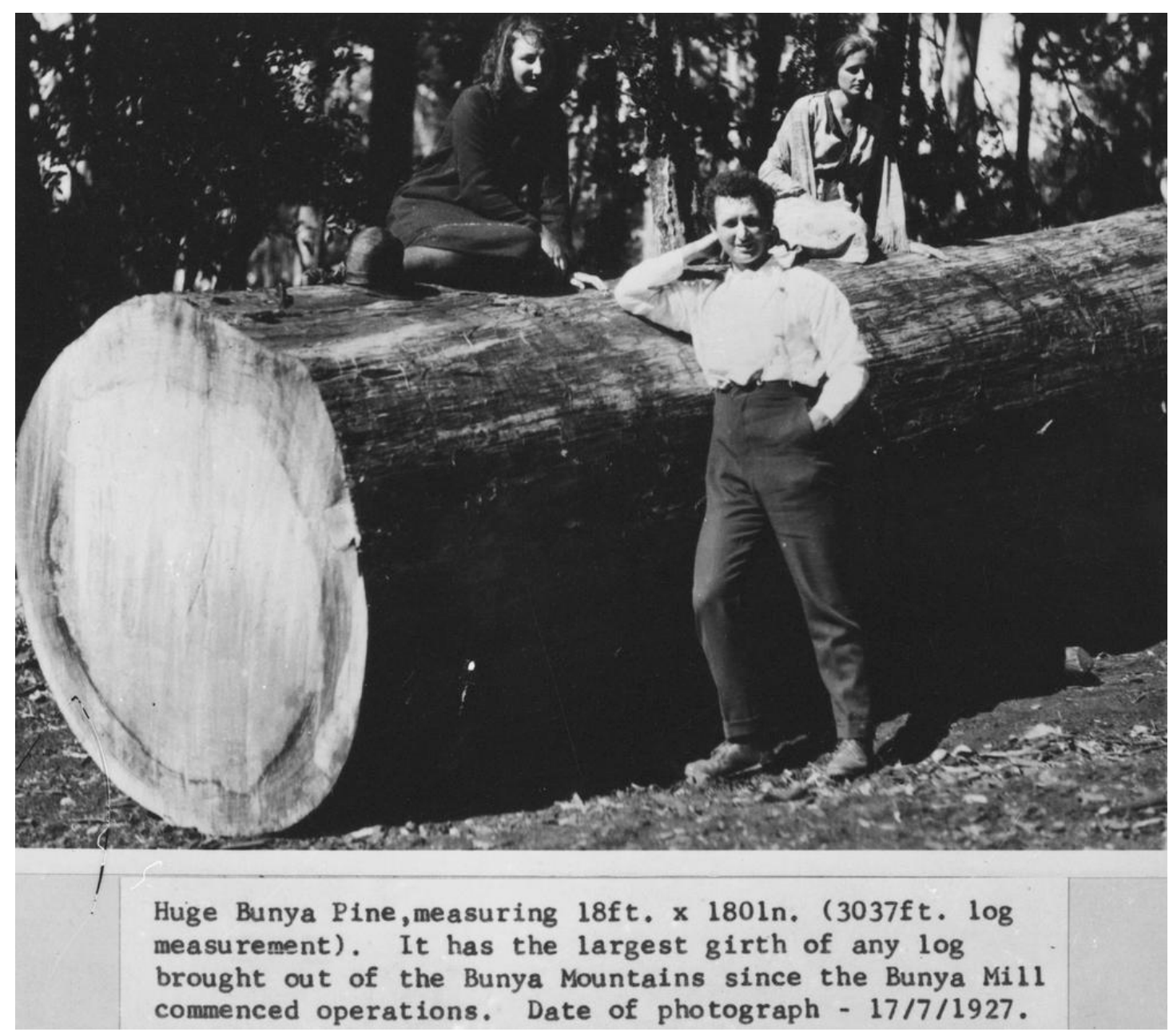

Figure 2. Unidentified (1927). Arthur Groom and bunya pine log, Bunya Mountains, 1927. Reproduced with permission, John Oxley Library, State Library of Queensland [caption in original] 


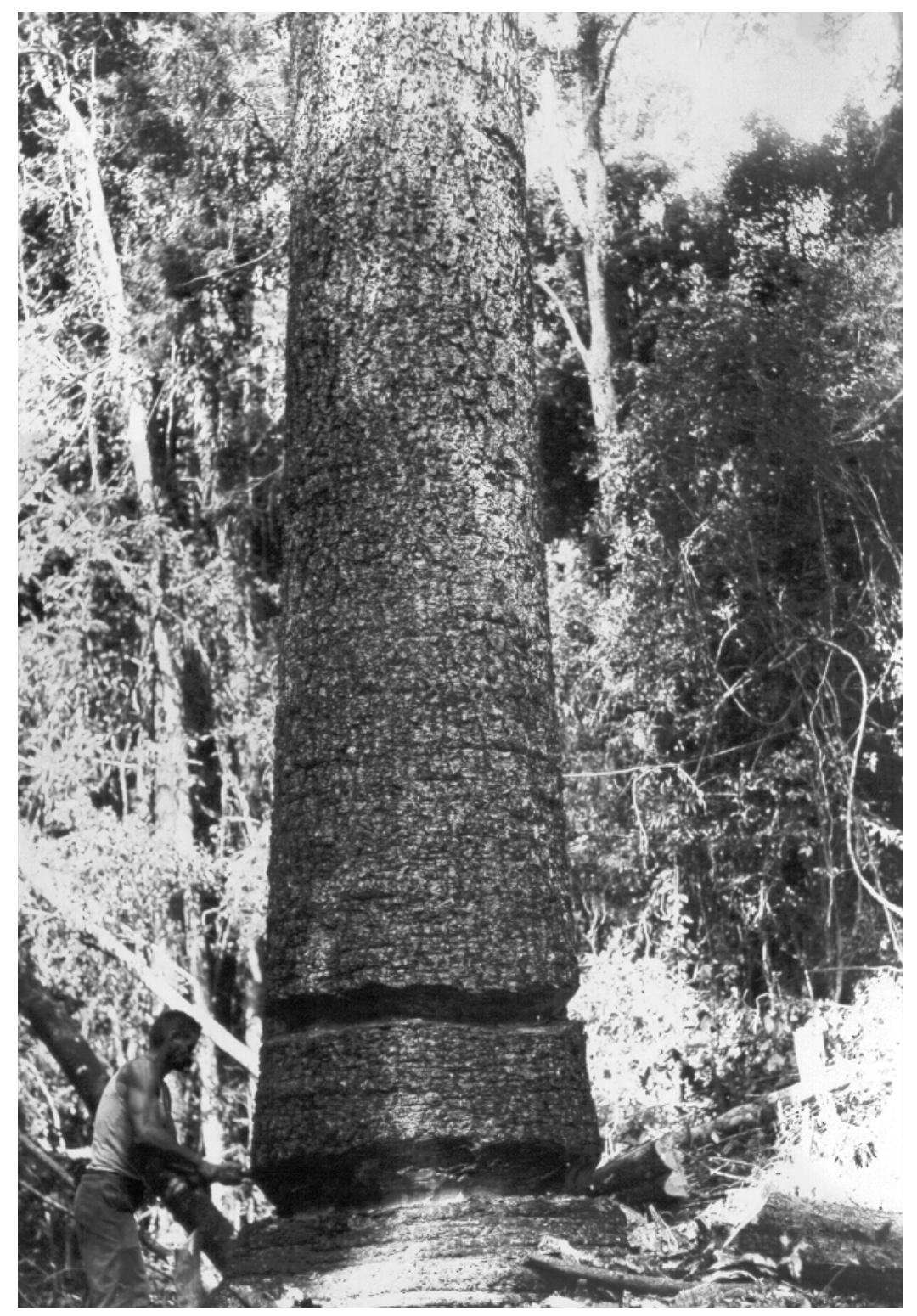

Figure 3. Harvesting bunya pine by hand, southeast Queensland. Reproduced with permission, Queensland Agriculture and Fisheries. 


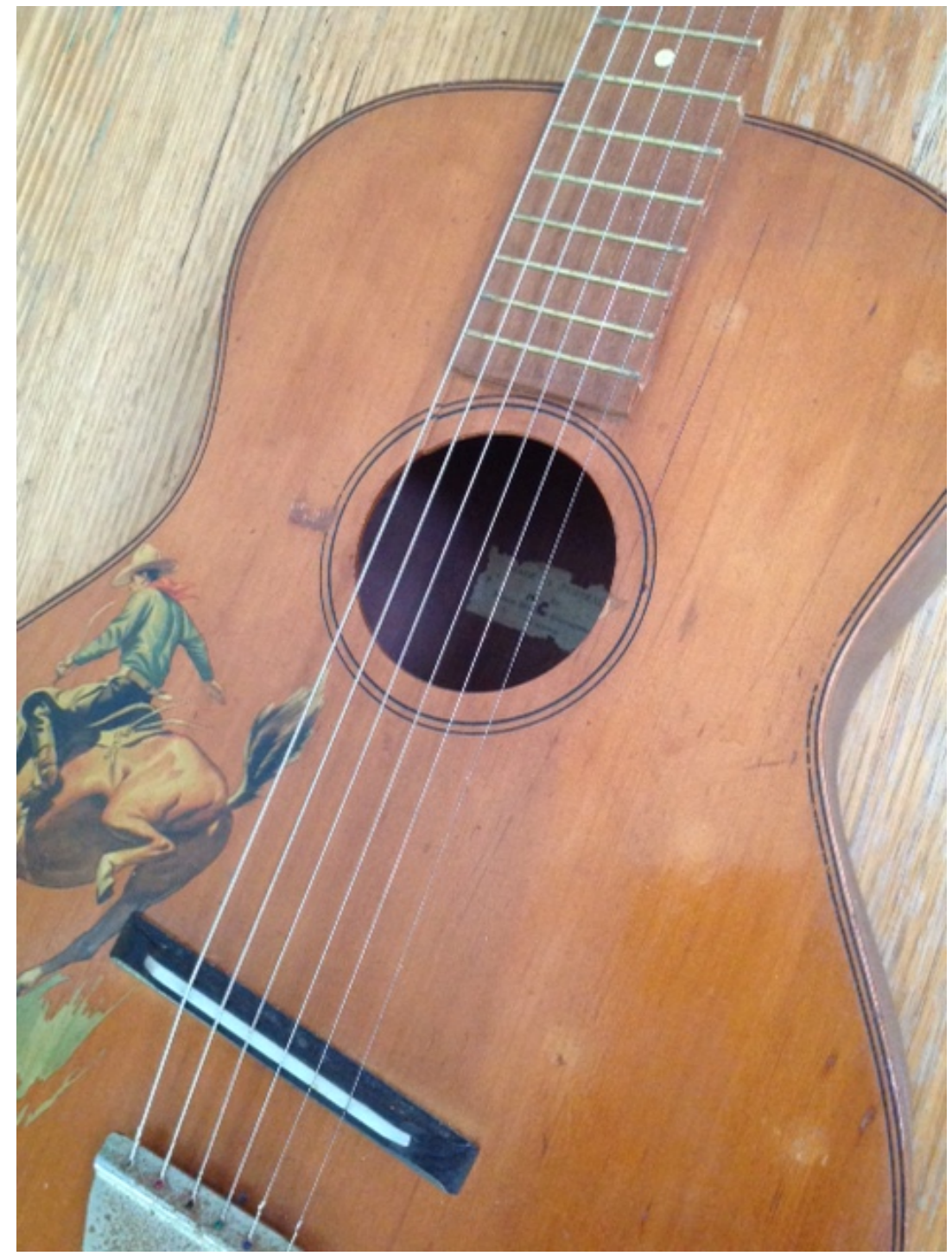

Figure 4. Maton/Alver 1A Flat Top Hillbilly Model (Queensland maple neck, blackean or silver silkwood fingerboard, and plywood top likely consisting of hoop or bunya pine, or both), c1958-1959. Source: Chris Gibson. 


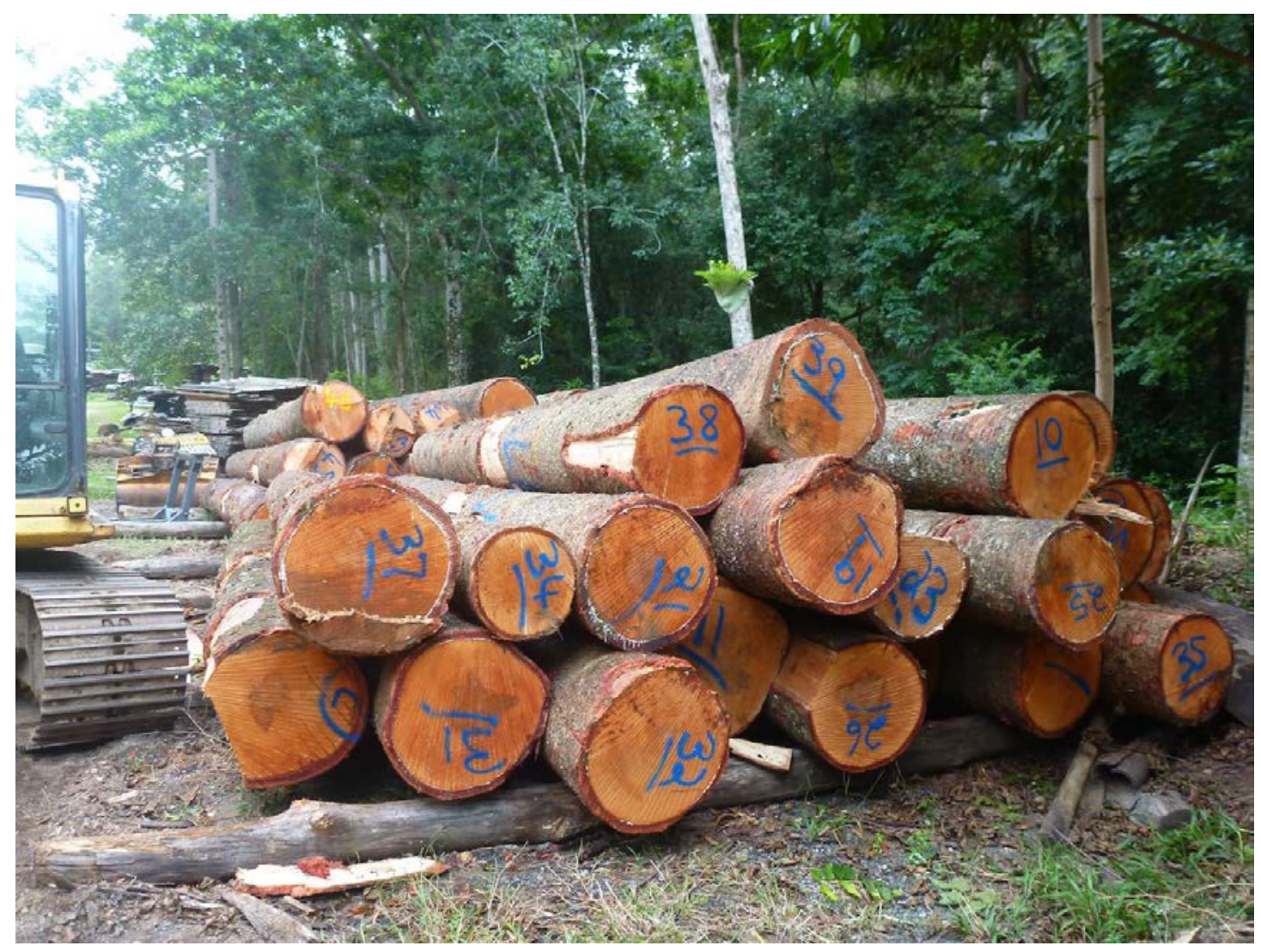

Figure 5a. A shipment of bunya pine logs arrives at Kirby Fine Timbers, Mooloolah Valley, Queensland, for processing into guitar soundboards, 2015. This equates to approximately 15 bunya trees, enough to supply the needs of Australian guitar manufacturers for a year. Reproduced with permission, David Kirby. 


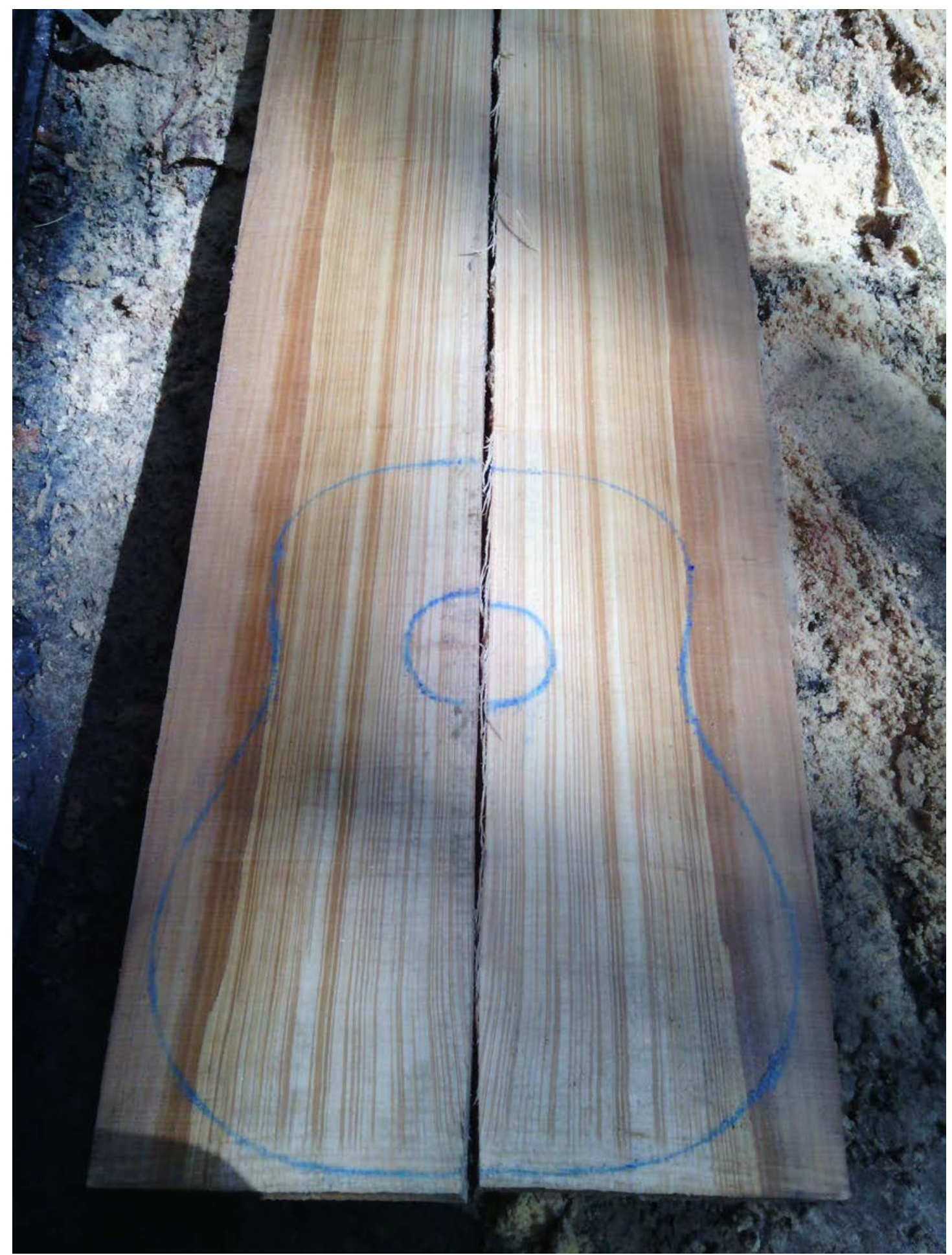

Figure 5b: processed bunya soundboards, Kirby Fine Timbers. Reproduced with permission, David Kirby. 


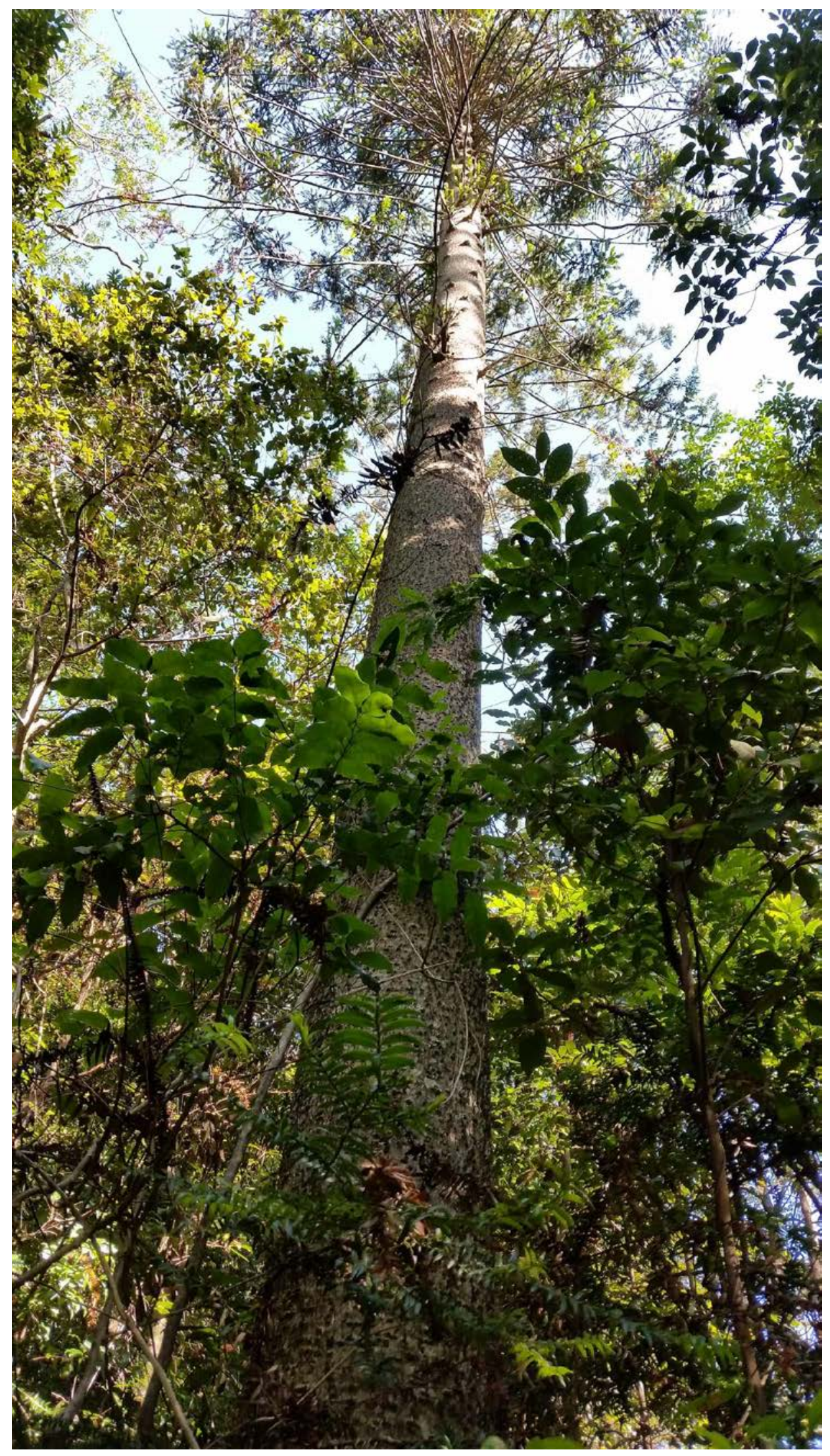

Figure 6: mature bunya tree, southeast Queensland. Reproduced with permission, David Kirby. 